\title{
RECONSTRUCTION PROTECTION OF LAW OF VICTIMS OF VICTIMS BASED ON JUSTICE VALUES
}

\author{
Ervin Hengki \\ A Police man in Resort Brebes Central Java \\ E-mail : ervinhengki123@gmail.com
}

\begin{abstract}
The crime of rape is the most difficult case in the settlement, either at the stage of investigation, prosecution, or at the stage of the adjudication of the verdict. Legal protection of victims of criminal rape in positive law in Indonesia is currently not based on the value of justice, because there are still weaknesses, namely the weakness of the law, the weakness of the approach / way of thinking of law enforcers, as well as the weaknesses during the criminal justice process.
\end{abstract}

\section{Keywords : Legal Protection, Victim, and Rape}

\section{A. INTRODUCTION}

The crime of rape is the most difficult case in the settlement either at the stage of investigation, prosecution, or at the stage of the decision. In addition to the difficulties in the limits above, also the difficulty of proof such as rape or lewd acts are generally done without the presence of others.

Many cases of rape are not reported to the authorities. The reasons for rape cases are not reported by the victim to the law enforcement officers to be prosecuted due to several factors, among which the victim is embarrassed and does not want the disgrace that befell him or herself, or the victim feels threatened by the perpetrator that he / killed if reporting the incident to the police. This of course affects the mental / psychological development of the victims and also affects the law enforcement process itself to bring about a sense of justice for victims and society. ${ }^{1}$

Although many of the crimes of rape have been processed to the court, but from those cases the perpetrators are not sentenced to the maximum in accordance with the provisions of the law contained in the Criminal Code (KUHP) CHAPTER XIV on Crime Against Decency ( Article 281 to Article 296).

With too light a criminal penalty imposed, the purpose of punishment as a special prevention

1 Leden Marpaung, Kejahatan Terhadap Kesusilaan Dan Masalah Prevensinya, Jakarta, Sinar Grafika, 2006, page. 81 and general prevention is not achieved optimally as expected. This is evidenced by the recent increase in criminal acts of rape, whereas the existence of sanctions provides direction and consideration of what should be used as sanctions in a criminal act to enforce the norm of justice. ${ }^{2}$

The criminal justice system takes over the right of the rape victim to deal with the crime that befell him, but in the workings of the criminal justice system has not been able to protect the rape victims. During this time the criminal justice system is more concerned with criminal acts and offenders, whereas victims especially in the case of rape victims are less attention, and in the imposition of criminal sanctions, often the judge gives too light a criminal sanction to the defendant who is proven to commit criminal rape. This, of course, is incompatible with the suffering experienced by rape victims, whose criminal rape has damaged his physical and mental well-being and destroyed his future.

One of the objectives of the criminal justice system is to protect people against crime and serve those who are victims of crime. At the level of law enforcement, rape victims are often ignored, in which the police are not acting on behalf of the reporting person, but his attention is directed at public order, to actions that endanger the environment and efforts to limit the sources of the occurrence of such disorder. In other words, law enforcement and order efforts are laid in the

2 Teguh Prasetyo, Kriminalisasi dalam Hukum Pidana, Nusa Media, Bandung, 2010, page 78. 
legal framework for society and are not designed to reduce the suffering of individuals or rape victims so as to generate discontent for rape victims. The protection of crime victims in the settlement of criminal cases is not only important for the victims and their families but also for the wider interests of crime on the one hand and on the other for the interests of the perpetrators themselves. The culprit who has done good to the victim will be easier in the case of the guardian, because then the perpetrator has felt do concretely to remove the stains caused by his crime. The criminal sanction in the form of an obligation to provide compensation to the victim will develop the responsibility of the perpetrator because in the implementation the active role of the perpetrator is required. ${ }^{3}$

In fact, in Indonesia, the protection of victims has been regulated in a separate law, where based on the principle of equality before the law which becomes one of the characteristics of the rule of law, witnesses and victims in the criminal justice process must be guaranteed legal protection namely by providing protection to witnesses based on Law Number 31 Year 2014 on the Protection of Witnesses and Victims, but in fact, at the level of law enforcement, rape victims are often ignored, where existing police and criminal justice sub-systems do not act on the interests of people to report, but his attention is directed to the public order, to the actions that endanger the environment and the efforts to limit the sources of the disorder arising, while the interests of the victims both in their protection and in the successful settlement of criminal proceedings and more extensively for the benefit of more broadly, ie for the benefit of crime prevention on the one hand and on the other for the benefit of the perpetrator of the crime itself.

The offender who has done good to the victim will be easier in terms of coaching, because then the perpetrator has felt acted concretely to remove the stains caused by his crime. Criminal imposition in the form of an obligation to provide compensation to the victim will develop the responsibility of the perpetrator

\footnotetext{
3 J.E. Sahetapy, Viktimologi Sebuah Bunga Rampai,
} Pustaka Sinar Harapan, Jakarta, 1987, page 43. because in the execution is required the active role of the perpetrator and also the victim itself.

Based on the background for the above research, the writer can formulate several problems as follows:

1. Why is the legal protection arrangement for victims of criminal rape in the positive criminal law currently not based on the value of justice?

2. How are the weaknesses of the legal protection of victims of criminal rape in the current positive criminal law?

3. What is the ideal construction of legal protection against criminal justice cased rape crime?

\section{B. Discussion}

1. The legal protection arrangements for victims of criminal rape in the positive criminal law are currently not based on justice values;

The crime of rape in the Criminal Code is regulated as a criminal act of morality contained from Article 281 of the Criminal Code up to Article 296 of the Criminal Code, but verkrachting in this case of intercourse is contained in Article 285 of the Criminal Code whose formula is as follows: "Whoever with violence or the threat of violence compels a woman to have sex with her outside of marriage, threatened with rape with a maximum of twelve years' imprisonment".

Rape victims are often double victims, in addition to suffering psychological distress, as well as in solving cases of crime of rape most difficult to cause either at the stage of investigation, prosecution, and at the stage of imposition of judgments, including in the case of the perpetrators of criminal acts of rape because in general events this happens in the absence of others. Many crimes of rape have been prosecuted. But in the settlement of the case, the perpetrator is not sentenced to the maximum in accordance with the provisions contained in the Criminal Code.

The main reason that many cases of rape crime are not known or hidden by the victim himself and not reported by the victim or family to law enforcement officers to be 
processed legally because the victim felt embarrassed and did not want to disgrace himself known by others and the victim was afraid of the threat the perpetrator that he would be killed if reporting the incident to the police.

The position of the victim in a criminal act as a party suffering and losing the offender's acts, then under the positive law the victim may claim harm or ask for compensation against the convicted person.

Legal provisions of legal protection against victims of criminal rape outside the Criminal Code and Criminal Procedure Code, namely only the implementation of such protection is also implicit, abstract and indirect. The renewal of the penal law as part of the penal policy does not only focus on the suspects but on the victims as well as the wider community. Therefore, with the existence of Law Number 31 Year 2014 concerning Protection of Witnesses and Victims, in particular what is stated in Article 5 point 1 concerning the protection of witness and victim's rights especially in the case of the protection of his personal, family and property, and is free of threats concerning testimony that he or she will be, or has been given information on, the progress of the case in court until the judge's judgment from the court, knowing the prisoner is released, and obtaining compensation, restitution and guarantee or compensation for social welfare.

On the basic paradigm that the victims of rape are the most disadvantaged, because the state guarantees the protection of personal, family, honor, dignity and property under his control, and the right of security and protection from the threat of fear to do or not to do, as mandated by the 1945 Constitution CHAPTER XA on Human Rights, especially Article 28G Paragraph (1). Therefore, the state is obliged to provide compensation and restitution, as well as guarantees or compensation for social welfare to the victims of rape. The community pendamba justice on July 18 , 2006 welcomed with the enactment of Law No. 13 of 2006 on Protection of Witnesses and Victims. The birth of Law Number 13 Year 2006 is expected to become a legal umbrella for the protection of witnesses and victims who have been felt less protected in the law of events in Indonesia.

The current criminal procedure law does not provide adequate protection for witnesses or victims related to a criminal case. In the General Elucidation of Law Number 13 of 2006 it is said that the Criminal Procedure Section 50 through Article 68 only regulates the protection of suspects and defendants against possible infringement of their rights. Therefore, based on equality before law, in the General Elucidation, witnesses and victims in the criminal justice process must be given a guarantee of legal protection. The protection of victims' rights starting from the level of investigation basically has a positive impact on the criminal justice process and creates a sense of justice for the citizens of the community, especially victims of crime.

The issuance of Law Number 23 Year 2004 on the Elimination of Domestic Violence, women, as victims of sexual violence perpetrated by husbands already have its own place, so that the perpetrators can already be threatened with criminal. Legal protection against victims of rape in Law Number 23 Year 2004 is a form of legal reform in Indonesia, which sides with vulnerable groups, especially women and children.

The protection of rape victims requires the participation of the people who empathize with what they have experienced, fulfilling the sense of humanity as set forth in the Pancasila 2nd Precept which reads: "Just and civilized humanity".

Based on all the provisions of legal protection against the rape victim, there are strengths and weaknesses of each. Article in the Criminal Code, there is no specified minimum threshold of imprisonment, no explicit explanation on the definition of intercourse and the imposition of sexual violence, and there is no direct rule on compensation.

Legal protection of rape victims is inadequate if observed and synchronized 
with international conventions and ideological principles this is due to legal protection in national law the absence of categorization of victims, forms of sexual violence against women, and categories of circumstances and place of rape. There is no necessity for the perpetrator to provide compensation to the victim and the victim's family who suffered losses. Absence of compensation from the state if the perpetrator is unable to compensate for economic reasons. The absence of the primacy of the victim in the case of the criminal act of rape.

Legal protection in the form of provision of restitution and compensation aims to restore the losses experienced by victims both physically and psychologically. The merger of indemnification lawsuits in cases of rape crime has never existed. This is because the merger of the indemnification lawsuit is very complicated and takes a long time because it must combine criminal and civil cases. This, of course, adds to the list of ineffectiveness of legislation.

2. Weaknesses of legal protection of victims of criminal rape in the current positive criminal law;

a. Weakness in terms of positive law substance;

b. The formulation of the crime of rape in Article 285 of the Criminal Code is considered discriminatory, and participates in standardizing the prevailing values in society regarding the dignity of women. In the eyes of Indonesian criminal law, especially the case of rape, the existence of women is reduced to the meaning of the vagina only, arranged only when the vagina is disturbed. The formulation of the rape article shows the standard of values / morals that society uses in treating women especially wives. A wife in a sexual relationship has no right to her husband. Accordingly, not only Article $\mathbf{2 8 5}$ of the Penal Code needs to be replaced, but also sociocultural values and myths which imply the presence of male dominance over women or each other needs to be replaced.

The element of intercourse meant the entry of the penis into the vagina (reproductive organs), required to actually enter and remove sperm. This understanding is still applied today, though this understanding comes from the Supreme Court's Decision (Hoge Raad), 5 February 1912.

Under Article 285 of the Criminal Code does not include rape in a household or husband raped his wife called marital rape. This provision does not prohibit rape of a wife by her husband. The weakness of the criminal law is also determined because of the age of the old Criminal Code as the mother of criminal law, originally Wetboek van Strafrecht (WvS) based on S. 1915 No. 732 valid from 1 January 1918.

The positive law indicates the arrangement of the inadequate victims, such as the provisions of Article $14 \mathrm{c}$ of the Criminal Code and Article 98-101 CHAPTER XIII KUHAP. In fact, the losses suffered by victims is very heavy. Women rape victims bear the mental burden heavier than the penalty for the rape. Victims will suffer lifelong disabilities and receive pressure from their community. Other effects include emotional disturbances as psychological burdens and subsequent psychological influences (eg schizophrenia) and physical (physiological disorder), fear, lack of security, unhappiness, feeling outcast, disability, and death. In addition, the scorn of the community, the feeling of distress felt that he was dirty and sinful. Moreover the pressures arising from the judicial process both before the trial, during the session, and after the session increasingly tell the victim. 
c. Weaknesses of the approach of law enforcement thinking (legal structure);

Criminal acts of rape that many occur in the reality of everyday life result in women arise fear, anxiety and insecurity. Moreover, supported by the victim's position which is often helpless in the criminal justice process. That is, the victim suffering is not bridged by law enforcement. To address all the legal inadequacies, the main required changes in legal thinking law enforcement. Positivistic analytics can no longer be maintained to underlie rape cases, which manifests that seeing the law is merely a law as a written rule, which is a juridical method in the narrow sense. For law enforcement officers, in connection with the development of current thinking on women's position and gender equality efforts need to base juridical thinking that links its social effects with the establishment of legal norms, so it is important to pay attention to the background of society. It is a juridical method in a broad sense, with the legal capacity to live in society, and utilizes an instrument of interpretive methods, such as extensive, sociological, or futuristic, as well as utilizing various articles of the Criminal Code on sexual harassment.

Thus, it is not a taboo to extend the notion of intercourse as an act of sexual intercourse in general that not only concerns the genital / reproductive apparatus but also includes the behavior of oral, anal and other acts of sexual urges. Similarly, the interpretation of coercion and the threat of violence.

Courage law enforcement officers to behave that way, if in law enforcement based on a vision, ie from the process of investigation to judge verdict, and execution-oriented to the interests of the victim. The question is not only who the perpetrators, what actions, but also how the fate of the victim. Law enforcement is the same as enforcing abstract ideas into reality, and these ideas include justice. In the case of rape is handled through the legal process until it is realized in the judge's decision to realize gender justice as a legal objective.

Strengthening the position of the victim needs to be done, as long as there is no adequate legal provisions, especially in the model of the procedural right model, then intensifying the service model becomes imperative. This is done with the assistance and guidance of rape victims, which is performed as a service by all parties involved in handling the case. Attention and protection of crime victims is one of the most pressing needs of countries to provide compensation, restitution and service to victims of crime, but it is still difficult to fight for the rights and interests of crime victims in the criminal justice system.

The victim is not only understood as the object of a crime but must also be understood as a subject that needs social and legal protection. Basically the victim is a good person, individual, group or community who has suffered losses directly impaired by his experience as a target of crime.

d. Weaknesses protection of victims of criminal rape from aspects of legal culture.

In Indonesia, which still adheres to Eastern adat very upholding the dignity of women, especially in terms of sanctity. If a victim of a rape crime is publicly displayed because it must be the subject of the judicial proceedings of the investigation, the trial for the reason of protecting his rights, then for the victims of the rape crime will add disgrace and open the disgrace 
he suffered. Victims of rape crimes in the community are many who cover up their shame until the reports of other new victims with a very forced they report what happened to law enforcement.

\section{The ideal construction of legal protection against victims of rape crime based on justice}

The legal reconstruction of the legal protection of victims of rape as a manifestation to combat crime of rape should be oriented not only to the quantity of legislation but to be oriented towards the quality or the extra legal values of law reform, in other words, efforts to reduce the increase in criminal acts both in quantity and quality that has been focused only on technical efforts. In addition, in the criminal law enforcement the view that the victim only serves as a supporting instrument in exposing the material truth, namely as a mere witness.

The new concept of rape must be with the awareness or desire to design a criminal law space into the monodualistic concept, ie its attention not only to the perpetrator, but to the community.

The legal reconstruction of the legal protection of victims of rape as part of the penal policy does not only focus on the suspects but also on the victims as well as the wider community. Therefore, with the enactment of Law Number 31 Year 2014, particularly those listed in Article 5 point 1 concerning the protection of the rights of witnesses and victims, especially in the case of the protection of their personal, family and property, and free from threats with respect to the testimony that will be, is, or has been given; obtain information on the progress of the case he experienced in the proceedings until the judge's decision from the court; knowing the convicted person is released; and obtaining compensation, restitution, and guarantees or compensation for social welfare.

Legal protection of victims of crime of rape based on justice value against several articles in the Criminal Code after reconstruction:
1. Article 285 of the Criminal Code Anyone with violence or the threat of violence compels a woman to have sex with him outside of marriage, threatened for rape, with a minimum of twelve years and a maximum of 20 years in prison and compensation to the victim at least $R p 20.000 .000$, - (two tens of millions of rupiah) and a maximum of $\operatorname{Rp~1,000,000,000}$ (one billion rupiah), and provides health and rehabilitation services for victims.

2. Article 286 of the Criminal Code Anyone who has intercourse with a woman outside marriage, when it is known that the woman is in a state of unconsciousness or powerless, is punishable by imprisonment with a minimum sentence of twelve years and a maximum of 20 years and compensating the victim at least Rp20. 000,000, - (twenty million rupiahs) and a maximum of $R p 1,000,000,000.00$ (one billion rupiah), as well as providing health and rehabilitation compensation for the victims.

3. Article 287 of the Criminal Code Regulated separately based on Law Number 35 Year 2014 accompanied by an obligation for the perpetrator to provide compensation to the victim or the victim's family of at least Rp25.000.000, - (twenty five million rupiah) and a maximum of Rp10.000.000.000, - (ten billion rupiah).

4. Article 288 of the Criminal Code Regulated separately based on Law Number 35 Year 2014 accompanied by obligation for the perpetrator to give compensation to the victim or the victim's family at least $R p 35.000 .000$, - (thirty five million rupiah) and maximum of Rp10.000.000.000, (ten billion rupiah).

5. Article 289 of the Criminal Code Anyone with violence or the threat of violence forces a person to commit 
or allow obscene acts, threatened for committing an act that attacks the honor of morality, with imprisonment of at least 9 (nine) years and a maximum of 12 (twelve) years and providing a guarantee of restoration of the victim's good name minimum Rp20.000.000, - (twenty million rupiah) and a maximum of Rp1.000.000.000, - (one billion rupiah).

6. Article 290 of the Criminal Code Regulated separately based on Law Number 35 Year 2014 with the obligation for the perpetrator to compensate and compensate the victim or the victim's family at least $\mathrm{Rp} 35,000,000$, - (thirty five million rupiah) and a maximum of Rp10,000,000,000 (ten billion rupiah).

\section{CONCLUSION}

The legal protection arrangements for victims of criminal rape in positive law in Indonesia are not currently based on justice values because they have not involved victims in the judicial process and have not been explicitly regulated on the rights of victims of compensation, fines, guarantees and restitution rights as in the Criminal Code. Victims of rape are often double victims in addition to suffering psychological distress, as well as in the settlement of criminal cases of rape most often cause difficulties both at the stage of investigation, prosecution, and at the stage of imposition of judgments including in the case of the perpetrators of criminal acts of rape because in general these events occur without the presence of others. In Law No. 31 of 2014, legal protection against rape victims is inadequate when viewed and synchronized with international conventions and victomologi principles. The absence of a requirement for the perpetrator of the crime to provide compensation to the victim and the victim's family who suffered a loss.

The weaknesses of the legal protection of victims of crime of rape in the current positive law, namely the weakness of the law, the weakness of the approach / way of thinking of law enforcers, the weaknesses during the criminal justice process and the weaknesses of the legal culture aspects, among others.

The reconstruction of legal protection against victims of justice-based rape crime can be seen from viktuologi as the basis of reconstruction of legal protection against victims of rape crime, can be viewed from the criminalization of perpetrators of rape crime based on the value of justice, based on legal protection against victims of crime rape in various countries, based on the idea of progressive legal theory on the reconstruction of legal protection of victims of rape, and the reconstruction of legal compensation for victims.

Protection of victims of rape should be reconstructed, especially in the granting of the rights of victims of criminal acts of rape in the draft law that in order to obtain maximum protection, crime victims have a right to be considered. The rights of victims of rape crimes that must be re-constructed are among others formulated as follows.

a. The victim must receive compensation for his misery. Such compensation shall be in accordance with the ability to provide harm from the offender and the level of involvement of the victim in the commission of such crime and deliberation;

b. The victim also has the right to refuse restitution for the perpetrator's interest (refusing to be refunded for not requiring);

c. The victim receives restitution / compensation to the heirs, if the victim dies because of a crime perpetrated by the perpetrator;

d. Victims should receive coaching and rehabilitation from the government;

e. The victim gets his property back;

f. The victim receives protection from the perpetrator's threat when reporting the crime that befell her, and if a witness to the crime;

g. Victims get legal aid;

h. Victims are entitled to use legal remedies. 


\section{BIBLIOGRAPHY}

J.E. Sahetapy. 1987. Viktimologi Sebuah Bunga Rampai, Jakarta : Pustaka Sinar Harapan.

Leden Marpaung. 2006. Kejahatan Terhadap Kesusilaan Dan Masalah Prevensinya, Jakarta : Sinar Grafika.

Peter Mahmud Marzuki 2009. Penelitian Hukum, Jakarta : Kencana.

Teguh Prasetyo. 2010. Kriminalisasi dalam Hukum Pidana. Bandung : Nusa Media.

Undang-Undang Dasar Negara Kesatuan Republik Indonesia Tahun 1945.

Kitab Undang-Undang Hukum Pidana.

Kitab Undang-Undang Hukum Acara Pidana.

Undang-Undang Nomor 23 Tahun 2004 tentang Penghapusan Kekeras-an Dalam Rumah Tangga.

Undang-Undang Nomor 13 Tahun 2006 jo. Undang-Undang Nomor 31 Tahun 2014 tentang Perlindungan Saksi dan Korban. 